\title{
Vitamin D and disease activity in rheumatoid arthritis patients: a retrospective study in a Romanian cohort
}

\author{
Elena Sirbu ${ }^{1 \otimes}$, Florina Buleu ${ }^{2}$, Anca Tudor $^{3}$ and Simona Dragan ${ }^{2}$ \\ 'Department of Physical Therapy and Special Motricity, West University of Timişoara, Romania; 'Departament of Cardiology, University of Medi- \\ cine and Pharmacy "Victor Babeș", Timișoara, Romania; 'Department of Medical Informatics, University of Medicine and Pharmacy "Victor Babeș", \\ Timișoara, Romania
}

Background. The relationship between the serum levels of Vitamin D and the severity of RA is a subject of great interest for the future therapeutic strategies. Although the evidence on the relationship between hypovitaminosis D and early RA is contradictory, preliminary data suggest that the serum levels of vitamin $D$ are inversely associated with the disease activity. Aim: the main objectives of this study include: (1) to analyze the serum levels of vitamin $D$ in patients with RA in comparison to healthy controls; (2) to investigatea possible correlation with disease activity. Materials and Methods. This was a retrospective, comparative study conducted on 37 subjects suffering from RA and a group of 21 healthy matched controls. The following were determined in all studied subjects: erythrocyte sedimentation rate (ESR), white blood cells (WBC), hemoglobin $(\mathrm{Hb})$, platelets (PLT), serum calcium (Ca), serum phosphorus (Phos), and serum 25 hydroxy-vitamin D. Moreover, in the RA group the IgM-Rhematoid Factor (RF) and anti-citrullinated protein antibodies (ACPA) (immune-enzymatic method) were assessed. The Disease Activity Score of 28 joints (DAS28) was calculated for the RA patients. Results. We observed that vitamin $D$ deficiency is more common in RA patients than in healthy controls. No significant correlation between 250 HvitD and DAS28-ESR was found in our study cohort. Conclusions. There is no significant association of serum $25(\mathrm{OH}) \mathrm{D}$ with disease severity in a Western Romanian cohort with RA. However, this result could have implications for the disease management, as patients with RA could be supplemented with vitamin D even in the absence of disease activity.

Key words: Disease activity, rheumatoid arthritis, $25(\mathrm{OH})$ vitamin $\mathrm{D}$, DAS 28

Received: 03 May, 2020; revised: 31 May, 2020; accepted: 03 June, 2020; available on-line: 18 June, 2020

Đe-mail: elena sarbu@yahoo.co.uk

Abbreviations: RA, rheumatoid arthritis; ESR, erythrocyte sedimentation; WBC, white blood cells; $\mathrm{Hb}$, hemoglobin; PLT, platelets; $\mathrm{Ca}$, serum calcium; Phos, serum phosphorus; ACPA, anti-citrullinated protein antibodies; $25(\mathrm{OH}) \mathrm{D}$, serum 25 hydroxy-vitamin $\mathrm{D} ; 25(\mathrm{OH})$ D3, calcifediol; $1,25(\mathrm{OH}) 2 \mathrm{D}$, calcitriol; DMARDS, disease modifying antirheumatic drugs; DAS28, disease activity score 28

\section{INTRODUCTION}

Vitamin D refers to a group of fat-soluble secosteroids with an important role in phospho-calcic metabolism. In humans, vitamin D circulates in two forms: vitamin D2 (ergocalciferol) and vitamin D3 (cholecalciferol).

Vitamin D3 is metabolized in the liver to 25-hydroxyvitamin D3 [25(OH)D3] (calcifediol), and it represents the major circulating form of vitamin D. In the kidneys, $25(\mathrm{OH}) \mathrm{D} 3$ is additionally hydroxylated to 1,25 dihydroxyvitamin $\mathrm{D}\left(1,25(\mathrm{OH})_{2} \mathrm{D}\right)$ or calcitriol, being the active form of vitamin D. Because of its long half-life and higher concentration, 25-hydroxyvitamin D $[25(\mathrm{OH})$ D3] is commonly measured to assess and monitor the vitamin D status in individuals (Feldmann et al., 2017).

Lately, there is a growing interest in the assessment of vitamin $\mathrm{D}$ status in several autoimmune diseases.

Rheumatoid arthritis (RA), an autoimmune progressive systemic disease of the connective tissue, is particularly manifested by destructive alterations in the joints and synovitis (Bumbea et al., 2017).

It is known that RA affects $0.72 \%$ of the worldwide population and occurs more frequently in women over 40 years of age (Myasoedova et al., 2020). Studies on the incidence and prevalence of RA suggest variations between different populations even within the same country. For instance, in Romania, 200000 people suffer from arthritis, and women are three times more likely to develop RA (Șuța et al., 2014).

The etiology and pathogenesis of RA is still obscure and many factors can be involved. The etiology of the disease could be attributed to genetic and non-genetic factors, such as hormonal, environmental, and infectious factors. Moreover, it has been shown that vitamin $\mathrm{D}$ is an environmental risk factor involved in the pathogenesis of this disease (Cutulo et al., 2009).

Vitamin D receptors have been identified in the areas of cartilage erosion, in the chondrocytes and synoviocytes of patients with RA. Thus, detection of vitamin D receptors in the immune system cells may elucidate associations between this vitamin and RA (Tetlow et al., 1999).

Already known to have an important role in osteoporosis and fractures, which are frequent complications in RA (Bellan et al., 2019; Tan et al., 2018), and also in the modulation activities of the immune cells, including lymphocytes and macrophages (Marques et al., 2010), vitamin D can be the key factor leading to the development or worsening of the disease.

Some epidemiological studies showed that vitamin D deficiency is common in RA patients when compared to the healthy population (Haque et al., 2010; Kerr et al., 2011), whereas other investigations did not confirm these findings (Cutolo et al., 2006; Turhanoğlu et al., 2010).

Due to these controversies that have not yet demonstrated whether vitamin D deficiency is a result or primary phenomenon of RA, new findings are needed to help understand the association between the RA disease activity and levels of $25(\mathrm{OH}) \mathrm{D}$. 
Therefore, the main objectives of this retrospective study include: (1) to analyze serum levels of $25(\mathrm{OH}) \mathrm{D}$ in patients with RA in comparison to healthy matched controls; (2) to investigate a possible correlation with disease activity.

\section{METHODS}

Study population. The study was performed on a group of 37 patients with RA and 21 healthy subjects matched for age and gender, as controls.

Patients were included in this study only if they met all of the following criteria: 1. Adults aged $>30$ years, 2. Definite diagnosis of RA according to the 1987 ACR criteria, 3. Disease duration for more than 1 year, 4. Treatment with at least one or more disease modifying antirheumatic drugs (DMARDS) or biologic agents, but not cortisone, 5. Data were collected during winter.

Exclusion criteria were as follows: cardiopulmonary diseases, diabetes mellitus treated by insulin, uncontrolled arterial hypertension, dyslipidemia, chronic kidney disease, thyroid dysfunction, Cushing's syndrome, osteoporosis, current smokers, diseases associated with hypercalcaemia (lymphoma, sarcoidosis, tuberculosis infection, primary hyperparathyroidism), treatment with vitamin $\mathrm{D}$ and/or calcium supplementation or drugs affecting the bone and mineral metabolism.

The control group had no rheumatic diseases or other skeletal symptoms based on history and clinical examination.

Clinical measurements and laboratory tests. In all subjects, the following data were collected: age, gender, disease duration, body weight, height, and body mass in$\operatorname{dex}$ (BMI: $\mathrm{Kg} / \mathrm{m}^{2}$ ).

Blood samples were taken from all patients in order to assess: erythrocyte sedimentation rate (ESR), white blood cells (WBC), hemoglobin (Hb), platelets (PLT), serum calcium (Ca), serum phosphorus (Phos), using standard laboratory methods. The IgM-Rhematoid Factor (RF) (nephelometric method) and anti-citrullinated protein antibodies (ACPA) (immune-enzymatic method) were also assessed. In order to evaluate vitamin D status in our study population, serum levels of $25(\mathrm{OH})$ vitamin $\mathrm{D}(\mathrm{ng} / \mathrm{ml})$, the most stable circulating form of this molecule, were also measured using the chemiluminescent immunoassay technique.

In controls, the following were determined: erythrocyte sedimentation rate (ESR), white blood cells (WBC), hemoglobin (Hb), platelets (PLT), serum calcium (Ca), serum phosphorus (Phos), and vitamin D levels, using the same methods.

The rheumatoid arthritis activity was assessed using the Disease Activity Score 28 (DAS28). DAS28 was calculated based on ESR, tender joint count (28 joints), swollen joint count ( 28 joints), and the patient's assessment of global well-being $(100 \mathrm{~mm}$ visual analogue scale).

High disease activity was defined as DAS28 $>5.1$, moderate disease activity was defined as $3.2<$ DAS $28 \leq 5.1$, and low disease activity was defined as $2.6 \leq \mathrm{DAS} 28 \leq 3.2$, while remission was set as DAS $28 \leq 2.60$ (Feser et al., 2009).

Values of vitamin $\mathrm{D} \geq 30 \mathrm{ng} / \mathrm{ml}$ were considered as normal, while vitamin D insufficiency was defined as a level between 15 and $29 \mathrm{ng} / \mathrm{ml}$, and vitamin deficiency at levels $<15 \mathrm{ng} / \mathrm{ml}$ (Watson, 2013).

All subjects gave their informed consent for inclusion before they participated in the study. This study was conducted in accordance with the Declaration of Helsinki, and the protocol was approved by the Institutional Ethics Committee.

Characteristics of RA patients and controls. The two groups were similar in terms of age, height, weight and BMI. Thus, mean age in the RA patients and control group was $57 \pm 12.58$ and $50.19 \pm 16.41$, respectively. Also, the mean BMI of the RA patients was $26.48 \pm 4.44$ $\mathrm{kg} / \mathrm{m}^{2}$ versus $26.76 \pm 3.6 \mathrm{~kg} / \mathrm{m}^{2}$ of the controls, indicating an overweight sample.

A higher level of serum ESR was observed in RA patients, when compared to bealthy controls.

RA patients were positive for the rheumatoid factor and anticitrullinated peptide antibodies. All patients enrolled in the study received a DMARD treatment without concomitant corticosteroids or vitamin D supplementation. Thus, $56.8 \%$ of the patients received methotrexate, $32.4 \%$ leflunomide, and $5.45 \%$ sulfasalazine.

Statistical analysis. Data analysis was performed using SPSS v.17. Continuous variables were presented as mean and standard deviations, and nominal data were presented as counts (percentages). We performed a descriptive and inferential statistics analysis to summarize the characteristics of the study population. In order to evaluate the proportion of categorical data in the groups, we applied the chi-squared test $\left(\chi^{2}\right)$. The results of the Shapiro-Wilk normality test showed a non-Gaussian distribution, which is why we continued to use nonparametric tests. To compare patients with/without RA or vitamin D deficiency, we applied the Mann-Whitney U test. In order to highlight the relationship between group characteristics and levels of vit D we performed Spearman's correlation. A multivariate linear regression analysis was used to evaluate the independent factors associated with the DAS28 variable and risk of vit D deficiency. A p value of less than 0.05 was considered to indicate statistical significance.

\section{RESULTS}

The demographic data of patients and controls are presented in Table 1.

We registered significant differences between the groups, with lower mean values of $25(\mathrm{OH})$ vitD in the RA patients than in the controls $(p=0.003)$.

$25(\mathrm{OH})$ vitD deficiency, insufficiency, and sufficiency were found in 30\% $(n=11), 54 \%(n=20)$ and $16 \%(n=6)$ of the RA patients, while $25(\mathrm{OH}) \mathrm{D}$ deficiency, insufficiency and sufficiency were found in $9 \%(\mathrm{n}=2), 43 \%$ $(n=9)$ and $48 \%(n=10)$ of the controls.

In our study group, the mean score of DAS28-ESR was $3.59 \pm 1.05$, providing a moderate disease activity group. Moreover, the 25-OH vitamin D levels of the patients from the high disease activity group were found to be the lowest, but they were not significantly different between the groups.

The Spearman nonparametric correlation test revealed that there was a significantly weak positive correlation between DAS28, WBC $(p=0.013)$ and Phos $(p=0.049)$. In contrast, correlation was strong in the case of ESR $(p<0.001)$ ('Table 2).

We found no significant correlation between $25 \mathrm{OH}-$ vitD and DAS28 or other studied parameters.

Following the linear regression analysis, only ESR was established as a significant predictive factor for DAS28 $(p=0.003)$ (Table 3).

The baseline characteristics of RA patients according to the disease activity are presented in Table 4. About 
Table 1. Characteristics of RA patients $(n=37)$ and healthy controls $(n=21)$

\begin{tabular}{|c|c|c|c|}
\hline Variable & RA patients & Healthy controls & $P$ \\
\hline Age (years)a & $57 \pm 12.58$ & $50.19 \pm 16.41$ & 0.083 \\
\hline Female $(\%)^{b}$ & $28(75.7 \%)$ & $21(100 \%)$ & $0.012^{*}$ \\
\hline Disease duration (years) ${ }^{a}$ & $2.73 \pm 2.22$ & - & - \\
\hline Height $(\mathrm{cm})^{\mathrm{a}}$ & $164.97 \pm 8.49$ & $163.81 \pm 6.19$ & 0.820 \\
\hline Weight $(\mathrm{kg})^{\mathrm{a}}$ & $72.19 \pm 14.29$ & $71.78 \pm 10.43$ & 0.428 \\
\hline BMI $(\mathrm{kg} / \mathrm{m} 2)^{\mathrm{a}}$ & $26.48 \pm 4.44$ & $26.76 \pm 3.6$ & 0.588 \\
\hline WBC $(\times 1000 / \mu \mathrm{L})^{\mathrm{a}}$ & $7.01 \pm 2.1$ & $7.63 \pm 1.99$ & 0.234 \\
\hline $\mathrm{Hb}(\mathrm{g} / \mathrm{dl})^{\mathrm{a}}$ & $12.9 \pm 1.68$ & $13.76 \pm 0.96$ & $0.031^{*}$ \\
\hline $\operatorname{PLT}(\times 1000 / \mu \mathrm{L})^{a}$ & $269.68 \pm 99.06$ & $261.86 \pm 75.5$ & 0.871 \\
\hline $250 H$ Vit D $(\mathrm{ng} / \mathrm{ml})^{\mathrm{a}}$ & $20.34 \pm 8.36$ & $27.87 \pm 9.81$ & $0.003^{*}$ \\
\hline $\mathrm{Ca}(\mathrm{mmol} / \mathrm{l})^{\mathrm{a}}$ & $9.48 \pm 0.41$ & $9.27 \pm 0.41$ & 0.099 \\
\hline Phos $(\mathrm{mmol} / \mathrm{l})^{\mathrm{a}}$ & $3.27 \pm 0.67$ & $4.28 \pm 0.94$ & $<0.001^{*}$ \\
\hline $\operatorname{ESR}(\mathrm{mm} / \mathrm{h})^{\mathrm{a}}$ & $25.54 \pm 20.18$ & $12.33 \pm 10.14$ & $0.002^{*}$ \\
\hline DAS28-ESRa & $3.59 \pm 1.05$ & - & - \\
\hline $\begin{array}{l}\text { Treatment: } \\
\text { Leflunomide (\%)b } \\
\text { Methotrexate (\%) } \\
\text { Sulfasalazine }(\%)^{\mathrm{b}}\end{array}$ & $\begin{aligned} 12 & (32.4 \%) \\
21 & (56.8 \%) \\
2 & (5.4 \%)\end{aligned}$ & - & - \\
\hline
\end{tabular}

aMean \pm S.D.; Mann-Whitney U Test; bnumber (percentage); Chi-square test; significance threshold value reached

Table 2. Correlation between DAS28 and other studied parameters (Spearman nonparametric correlation test)

\begin{tabular}{llllllllll}
\hline DAS28 & Age & Disease duration & BMI & WBC & Hb & PLT & Ca & Phos mmol/l & ESR \\
\hline Spearman Coefficient & -0.038 & -0.273 & -0.071 & $0.405^{*}$ & -0.189 & -0.019 & 0.079 & $0.326^{*}$ & $0.693^{*}$ \\
\hline$p$ - value & 0.825 & 0.102 & 0.676 & 0.013 & 0.263 & 0.912 & 0.644 & 0.049 & $<0.001$ \\
\hline
\end{tabular}

*Significance threshold value reached

Table 3. Predicted variables of the linear regression model (by the Enter method) considering DAS28 as the dependent variable

\begin{tabular}{|c|c|c|c|c|c|}
\hline \multirow{2}{*}{ Predictors } & \multicolumn{2}{|c|}{ Unstandardized coefficients } & \multirow{2}{*}{$\begin{array}{c}\text { Standardized coefficients } \\
\text { Beta }\end{array}$} & \multirow{2}{*}{$\mathrm{T}$} & \multirow{2}{*}{ Sig. } \\
\hline & B & Std. Error & & & \\
\hline (Constant) & -19.624 & 33.354 & & -0.588 & 0.562 \\
\hline Age & -0.008 & 0.013 & -0.095 & -0.602 & 0.553 \\
\hline Disease duration & -0.112 & 0.073 & -0.237 & -1.543 & 0.136 \\
\hline Height & 0.124 & 0.188 & 0.998 & 0.656 & 0.518 \\
\hline Weight & -0.134 & 0.201 & -1.828 & -0.667 & 0.511 \\
\hline BMI & 0.346 & 0.551 & 1.460 & 0.628 & 0.536 \\
\hline WBC & 0.127 & 0.082 & 0.254 & 1.561 & 0.132 \\
\hline $\mathrm{Hb}$ & 0.072 & 0.124 & 0.116 & 0.582 & 0.566 \\
\hline PLT & -0.003 & 0.002 & -0.241 & -1.609 & 0.121 \\
\hline 25OHVitD & -0.026 & 0.021 & -0.204 & -1.199 & 0.242 \\
\hline $\mathrm{Ca}$ & 0.238 & 0.487 & 0.093 & 0.489 & 0.629 \\
\hline Phos (mmol/l) & 0.144 & 0.292 & 0.092 & 0.492 & 0.627 \\
\hline ESR & 0.031 & 0.009 & 0.600 & 3.356 & $0.003^{*}$ \\
\hline
\end{tabular}

*Significance threshold value reached 
Table 4. Characteristics of rheumatoid arthritis patients based on the disease activity status.

\begin{tabular}{|c|c|c|c|c|c|}
\hline Variable & $\begin{array}{l}\text { Remission } \\
\text { (DAS } 28<2.6)\end{array}$ & $\begin{array}{l}\text { Low disease activity } \\
(2.6 \leq \text { DAS } 28 \leq 3.2)\end{array}$ & $\begin{array}{l}\text { Moderate disease activity } \\
(3.2<\text { DAS } 28 \leq 5.1)\end{array}$ & $\begin{array}{l}\text { High disease activity } \\
\text { (DAS } 28>5.1 \text { ) }\end{array}$ & $p$ \\
\hline & $(\mathrm{N}=8,22 \%)$ & $(\mathrm{N}=7,19 \%)$ & $(\mathrm{N}=15,40 \%)$ & $(\mathrm{N}=7,19 \%)$ & \\
\hline $\mathrm{Age}^{\mathrm{a}}$ & $66.13 \pm 5.69$ & $48.29 \pm 13.34$ & $53.13 \pm 11.75$ & $63.57 \pm 11.13$ & $0.009^{*}$ \\
\hline Sex ${ }^{b}$ & $5(62.5 \%)$ & $5(71.4 \%)$ & $12(80.0 \%)$ & $6(85.7 \%)$ & 0.715 \\
\hline $\begin{array}{l}\text { Disease dura- } \\
\text { tiona }\end{array}$ & $2.44 \pm 1.24$ & $2.79 \pm 1.29$ & $3.2 \pm 2.91$ & $2 \pm 2.24$ & 0.292 \\
\hline Height $^{a}$ & $165.88 \pm 6.92$ & $164.57 \pm 12.03$ & $165.93 \pm 6.63$ & $162.29 \pm 10.83$ & 0.500 \\
\hline Weighta & $73.75 \pm 15.54$ & $72.14 \pm 16.21$ & $71.8 \pm 14.22$ & $71.29 \pm 14.28$ & 0.979 \\
\hline BMla & $26.63 \pm 3.66$ & $26.49 \pm 4.43$ & $26.19 \pm 5.65$ & $26.93 \pm 2.83$ & 0.814 \\
\hline WBCa & $6.58 \pm 2.45$ & $6.94 \pm 2.06$ & $6.35 \pm 1.35$ & $9.01 \pm 2.2$ & $0.025^{*}$ \\
\hline $\mathrm{Hb}^{\mathrm{a}}$ & $13.49 \pm 2.32$ & $12.99 \pm 1.43$ & $12.86 \pm 1.26$ & $12.21 \pm 1.98$ & 0.775 \\
\hline PLTa & $271.75 \pm 106.59$ & $287.14 \pm 122.16$ & $269.4 \pm 75.57$ & $250.43 \pm 128.76$ & 0.857 \\
\hline 25OHvitDa & $19.95 \pm 6.75$ & $22.55 \pm 9.44$ & $22.37 \pm 9.07$ & $14.24 \pm 5.06$ & 0.212 \\
\hline$C a^{a}$ & $9.52 \pm 0.5$ & $9.45 \pm 0.14$ & $9.33 \pm 0.4$ & $9.79 \pm 0.41$ & 0.152 \\
\hline Phosa & $3.17 \pm 0.87$ & $2.98 \pm 0.79$ & $3.3 \pm 0.62$ & $3.61 \pm 0.26$ & 0.181 \\
\hline $\mathrm{ESR}^{\mathrm{a}}$ & $12.38 \pm 4.14$ & $17.86 \pm 21.66$ & $27.53 \pm 17.3$ & $44 \pm 23.42$ & $0.003^{*}$ \\
\hline
\end{tabular}

aMean \pm S.D.; Kruskal-Wallis Test; bnumber (percentage); Chi-square test; * significance threshold value reached

$19 \%(n=7)$ of the participants were classified as showing high disease activity, $40 \%(n=15), 19 \%(n=7)$, and $22 \%$ $(n=8)$ were classified as having moderate, low disease activity, and in remission, respectively.

Although, age was significantly higher in the remission group and in the high disease activity group (KruskalWallis Test, $p=0.009$ ), no differences between the remission and the high disease activity groups were observed (Mann-Whitney U Test, $p=0.861$ ).

However, the mean value of vitamin $\mathrm{D}$ level was $14.24 \pm 5.06 \mathrm{ng} / \mathrm{mL}$ in the high disease activity group, $22.37 \pm 9.07 \mathrm{ng} / \mathrm{mL}$ in the moderate disease activity group, and $22.55 \pm 9.44 \mathrm{ng} / \mathrm{mL}$ in the low disease activity group.

Also, ESR values are significantly increased in the high disease activity group (Kruskal-Wallis test, $p=0.003$ ). However, the ESR values in the high disease activity group are not significantly different when compared to the moderate disease activity group (Mann-Whitney U test, $p=0.067$ ).

\section{DISCUSSION}

Our study showed that vitamin D deficiency and insufficiency are more prevalent in patients with RA than in healthy controls. The mean value of vitamin $D$ was significantly lower in the RA patients than in controls ( $p=0.003)$.

Although many studies have shown that vitamin D deficiency is common in RA, other studies did not find significant differences between RA patients and healthy controls (Craig et al., 2010; Cutolo et al., 2006; Hitchon et al., 2012; Turhanoğlu et al., 2010).

A large study from 15 countries, the COMORA study, explored the status of vitamin D in RA patients. The authors concluded that vitamin $\mathrm{D}$ deficiency, in patients with RA, varies between different countries. This variability may be explained by the association of many factors such as: racial or ethnic differences, climates, lack of sun exposure, skin color, clothing style, or latitude. Until recently, vitamin $\mathrm{D}$ insufficiency and deficiency were common in countries with less sun, particularly in North versus South Europe, with a circannual rhythm (Cutolo et al., 2006). In fact, current data indicates that tropical or subtropical areas, such as Central America and the Middle East, are also widely affected. This finding could be explained by several factors: avoidance of sun exposure, colored skin, wearing protective clothing, country latitude, vitamin $\mathrm{D}$ receptor (VDR) gene polymorphism and its expression (Vojinovic et al., 2017)

We believe that this variability is also determined by characteristics of the RA patients included in different studies, by inclusion and exclusion criteria taken into account or by methodology used in these studies.

Another large multicentric study collected data on vitamin D serum levels in 625 RA patients from 13 different European countries. Similarly to our study, the mean serum concentration of $25(\mathrm{OH}) \mathrm{D}$ in RA patients was significantly lower when compared to controls. $25(\mathrm{OH})$ $\mathrm{D}$ deficiency was found in $66 \%$ of the RA patients, and insufficiency was found in $27 \%$ of them (Merlino et al., 2004). On the contrary, in our study $54 \%$ of the patients had insufficiency, and only $30 \%$ had deficiency, while $16 \%$ of the RA patients had normal serum levels of vitamin D.

The study found a statistically significant difference in vitamin D levels between some European countries, with significantly higher $25(\mathrm{OH}) \mathrm{D}$ serum concentrations in RA patients from Spain, Latvia, and Serbia when compared to Romania (Merlino et al., 2004).

Although several studies have shown that vitamin D levels are inversely related to the RA disease activity, we found no correlation between the $25(\mathrm{OH}) \mathrm{D}$ levels and disease activity in our cohort. However, despite the lack of a significant correlation, our patient population had a well-controlled disease. This weak correlation may be explained by the absence of other assessed factors that could be involved in the functional deficiency of vitamin D (seasonal differences, sun exposure, nutritional status, skin color, clothing style, etc).

So far, evidence for the relationship between hypovitaminosis D and RA disease activity is contradictory (Ga- 
Table 5. Summary of the studies conducted on correlation between DAS and serum 25(OH)D values in RA patients

\begin{tabular}{|c|c|c|c|c|c|}
\hline $\begin{array}{l}\text { Author/year of publi- } \\
\text { cation/Country }\end{array}$ & $\begin{array}{l}\text { Mean age } \\
\text { (years) }\end{array}$ & $\begin{array}{l}\text { Number of } \\
\text { subjects }\end{array}$ & $\begin{array}{l}\text { Vitamin D } \\
\text { deficiency } \\
(\%)\end{array}$ & $\begin{array}{l}\text { Vitamin D } \\
\text { insufficiency } \\
(\%)\end{array}$ & Findings \\
\hline $\begin{array}{l}\text { Craig et al., 2010/ } \\
\text { USA }\end{array}$ & 51 & 266 RA patients & $49.6 \%$ & 14.7 & $\begin{array}{l}\text { Significant inverse correlation betwe- } \\
\text { en serum } 25(\mathrm{OHD}) \text { levels and DAS28 } \\
\text { (by univariate analysis) }\end{array}$ \\
\hline $\begin{array}{l}\text { Rossini et al., 2010/ } \\
\text { Italy }\end{array}$ & 58 & $\begin{array}{l}1191 \text { RA patients } \\
1019 \text { controls }\end{array}$ & $52 \%$ & - & $\begin{array}{l}\text { Inverse association of serum } \\
250 \text { HvitD levels with disease activity }\end{array}$ \\
\hline $\begin{array}{l}\text { Braun-Moscovici et al., } \\
\text { 2011/USA }\end{array}$ & 56 & 85 RA patients & $42.1 \%$ & - & $\begin{array}{l}\text { No correlation between vitamin D } \\
\text { levels and DAS28, ESR, CRP }\end{array}$ \\
\hline $\begin{array}{l}\text { Higgins et al., 2013/ } \\
\text { UK }\end{array}$ & 64 & 176 RA patients & $18 \%$ & $50 \%$ & $\begin{array}{l}\text { No significant correlation between } \\
\text { vitamin D and DAS28 scores with or } \\
\text { without the inclusion of VAS }\end{array}$ \\
\hline $\begin{array}{l}\text { Sahebari et al., 2014/ } \\
\text { Iran }\end{array}$ & 44 & $\begin{array}{l}99 \text { RA patients } \\
68 \text { controls }\end{array}$ & - & $75.7 \%$ & $\begin{array}{l}\text { No correlation between } 25(\mathrm{OH}) \mathrm{D} \\
\text { serum values and DAS28, duration of } \\
\text { disease, anti CCP, ESR, VAS, and the } \\
\text { number of tender and swollen joints. }\end{array}$ \\
\hline $\begin{array}{l}\text { Azzeh et al., 2015/ } \\
\text { Saudi Arabia }\end{array}$ & 50 & 102 RA patients & $57.8 \%$ & $31.4 \%$ & $\begin{array}{l}\text { Significant inverse correlation betwe- } \\
\text { en serum } 25(\mathrm{OHD}) \text { levels and DAS28 }\end{array}$ \\
\hline $\begin{array}{l}\text { Akkar et al., 2016/ } \\
\text { Morocco }\end{array}$ & 52 & 73 RA patients & $17.8 \%$ & $70 \%$ & $\begin{array}{l}\text { Vitamin D deficiency is associated } \\
\text { with higher disease activity }\end{array}$ \\
\hline $\begin{array}{l}\text { Gamal et al., } 2016 \\
\text { Egypt }\end{array}$ & 43.8 & $\begin{array}{l}55 \text { RA patients } \\
\text { and } 25 \text { healthy } \\
\text { controls }\end{array}$ & - & $21.8 \%$ & $\begin{array}{l}\text { Significant negative correlation be- } \\
\text { tween } 25(\mathrm{OH}) \mathrm{D} \text { and ESR } \\
\text { No correlation between } 25(\mathrm{OH}) \mathrm{D} \text { and } \\
\text { other parameters }\end{array}$ \\
\hline $\begin{array}{l}\text { Hajjaj-Hassouni et al., } \\
2017 / \\
\text { COMORA Study }\end{array}$ & 57.9 & 1413 RA patients & $8.5 \%$ & $54.6 \%$ & $\begin{array}{l}\text { Vitamin D levels were inversely cor- } \\
\text { related with disease activity DAS28 }\end{array}$ \\
\hline $\begin{array}{l}\text { Vojinovic et al., 2017/ } \\
\text { European multicentre } \\
\text { pilot study }\end{array}$ & 55 & $\begin{array}{l}625 \text { RA patients } \\
276 \text { controls }\end{array}$ & $66 \%$ & $27 \%$ & $\begin{array}{l}\text { Negative correlations were found } \\
\text { between } 25(\mathrm{OH}) \mathrm{D} \text { serum levels and } \\
\text { DAS28-CRP, and HAQ scores }\end{array}$ \\
\hline $\begin{array}{l}\text { Polasik et al., 2017/ } \\
\text { Poland }\end{array}$ & 48 & $\begin{array}{l}35 \text { RA patients } \\
38 \text { controls }\end{array}$ & $71.43 \%$ & $17.14 \%$ & $\begin{array}{l}\text { No significant correlation between } \\
\text { vitamin D and DAS28 scores or joint } \\
\text { damage (Steinbrocker criteria) } \\
\text { A positive correlation between } \\
25(\mathrm{OH}) \text { D and IL-6 was observed }\end{array}$ \\
\hline
\end{tabular}

mal et al., 2016; Higgins et al., 2013; Polasik et al., 2017; Rossino et al., 2010).

In a prospective cohort study on 29,368 women without a history of RA at baseline, it was demonstrated that low or deficient levels of $25(\mathrm{OH}) \mathrm{D}$ were inversely associated with the risk for development of RA ( $n=152)$ (Akkar et al., 2016). However, correlation between the disease activity and vitamin D deficiency has been demonstrated in many other studies (Azzeh et al., 2015; Braun-Moscovici et al., 2011; Hajjaj-Hassouni et al., 2017; Sahebari et al., 2014).

The findings of several studies included in our literature review and the characteristics of the study participants (mean age, number of subjects, vitamin D deficiency and insufficiency) are summarized in Table 5.

\section{Limitations of the study}

The study presented here has some limitations. The first limitation is the small sample size, being a singlecenter study. Study participants were enrolled from the Western part of Romania where sun exposure rates (and resulting vitamin D concentrations) may differ from other populations living in other geographical areas. Moreover, we did not assess other factors that could be involved in the functional deficiency of vitamin $\mathrm{D}$ (seasonal differences, sun exposure, nutritional status, skin color, clothing style, etc).
Secondly, only the serum $25(\mathrm{OH}) \mathrm{D}$ was determined, but not 1.25-hydroxyvitamin D. We did not collect data on parathyroid hormone levels or other parameters involved in vitamin $\mathrm{D}$ deficiency.

Finally, another limitation is the lack of a follow-up study in our population, given that all parameters were assessed only at enrollment.

\section{CONCLUSIONS}

We observed that vitamin D deficiency is more common in the RA patients than in the controls. There is no significant association of serum $25(\mathrm{OH}) \mathrm{D}$ with disease severity in a Western Romanian cohort with RA.

We found that the serum values of $25(\mathrm{OH}) \mathrm{D}$ are not a predictive factor for the disease activity in the RA patients. The hypothesis of vitamin $\mathrm{D}$ deficiency as a predisposing factor in triggering an increased activity of the disease needs to be tested on a larger group of RA patients. However, our results could have implications for disease management, as patients with RA could be supplemented with vitamin $\mathrm{D}$ even in the absence of disease activity.

\section{Conflict of interest}

The authors declare no conflict of interest. 


\section{REFERENCES}

Akkar O, Ichchou L (2016) Vitamin D status and its association with disease activity, severity and physical disability in rheumatoid arthritis patients. Ann Rheum Dis 75 (Suppl 2): 711. https://doi. org/10.1136/annrheumdis-2016-eular.5083

Azzeh FS, Kensara OA (2015) Vitamin D is a good marker for disease activity of rheumatoid arthritis disease. Dis Markers 260725. https:// doi.org/10.1155/2015/260725

Bellan M, Pirisi M, Sainaghi PP (2015) Osteoporosis in rheumatoid arthritis: role of the vitamin D/parathyroid hormone system. Rev Bras de Reumatol 55: 256-263. https://doi.org/10.1016/j.rbr.2014.10.007

Braun-Moscovici Y, Toledano K, Markovits D, Rozin A, Nahir AM, Balbir-Gurman A (2011) Vitamin D level: is it related to disease activity in inflammatory joint disease? Rheumatol Int 31: 493-499. https://doi.org/10.1007/s00296-009-1251-6

Bumbea AM, Mușetescu AE, Albulescu DM, Dumitrașcu RC, Bumbea BȘ, Popescu D, Albu VC (2017) The occurrence risk of demyelinating lesions in patients with rheumatoid arthritis and anti-TNF $\alpha$ biological therapy. Farmacia 65: 917-922

Craig SM, Yu F, Curtis JR, Alarcón GS, Conn DL, Jonas B, Callahan LF, Smith EA, Moreland LW, Bridges Jr SL, Mikuls TR (2010) Vitamin D status and its associations with disease activity and severity in African Americans with recent-onset rheumatoid arthritis. J Rheumatol 37: 275-281. https://doi.org/10.3899/jrheum.090705

Cutolo M (2009) Vitamin D and autoimmune rheumatic diseases. Rheumatol 48: 210-212. https://doi.org/10.1093/rheumatology/ken394

Cutolo M, Otsa K, Laas K, Yprus M, Lehtme R, Secchi ME, et al (2006) Circannual vitamin D serum levels and disease activity in rheumatoid arthritis: Northern versus Southern Europe. Clin Exp Rheumatol 24: 702-704

Feldmann D, Pike JW, Bouillon R, Giovannucci E, Goltzman D, Hewison M (2017) Vitamin D: Health, Disease and Therapeutic. In Vitamin D, 4th edn, pp 142-149. Academic Press.

Feser M, Derber LA, Deane KD, Lezotte DC, Weisman MH, Buckner JH, Mikuls T, O’Dell J, Gregersen PK, V Holers M, Norris JM (2009) Plasma 25, OH vitamin D concentrations are not associated with rheumatoid arthritis (RA)-related autoantibodies in individuals at elevated risk for RA. J Rheumatol 36: 943-946. https://doi. org/10.3899/jrheum.080764

Fransen J, Stucki G, Van Riel P (2003) Rheumatoid arthritis measures: disease activity score (DAS), disease activity score-28 (DAS28), rapid assessment of disease activity in rheumatology (RADAR), and rheumatoid arthritis disease activity index (RADAI) Arthritis Care Res 49, Suppl, pp S214-S224. https://doi.org/10.1002/art.11407

Gamal RM, Gaber W, Sayed S, Mohey AM, Goma SH, Mohamed MSE (2016) Vitamin D status in Egyptian patients with rheumatoid arthritis. Akt Rheumatol 41: 492-498. http://doi. org/10.1055/s-0035-1545308

Hajjaj-Hassouni N, Mawani N, Allali F, Rkain H, Hassouni K, Hmamouchi I, Dougados M (2017) Evaluation of vitamin D status in rheumatoid arthritis and its association with disease activity across 15 countries: "The COMORA Study". Int J Rheumatol 5491676. https://doi.org/10.1155/2017/5491676

Haque UJ, Bartlett SJ (2010) Relationships among vitamin D, disease activity, pain and disability in rheumatoid arthritis. Clin Exp Rheumatol 28: 745-747.

Higgins MJ, Mackie SL, Thalayasingam N, Bingham SJ, Hamilton J, Kelly CA (2013) The effect of vitamin D levels on the assessment of disease activity in rheumatoid arthritis. Clin Rheumatol 32: 863867. https://doi.org/10.1007/s10067-013-2174-x

Hitchon CA, Sun Y, Robinson DB, Peschken CA, Bernstein CN, Siminovitch KA, El-Gabalawy HS (2012) Vitamin D receptor polymor- phism rs2228570 (Fok1) is associated with rheumatoid arthritis in North American natives. J Rheumatol 39: 1792-1797. https://doi. org/10.3899/jrheum.120387

Kerr GS, Sabahi I, Richards JS, Caplan L, Cannon GW, Reimold A, Thiele GM, Johnson D, Mikuls TR (2011) Prevalence of vitamin D deficiency in rheumatoid arthritis and associations with disease severity and activity. J Rheumatol 38: 53-59. https://doi.org/10.3899/ jrheum.100516

Marques CD, Dantas AT, Fragoso TS, Duarte AL (2010) The importance of vitamin $\mathrm{D}$ levels in autoimmune diseases. Rev Bras de Reumatol 50: 67-80. https://dx.doi.org/10.1590/S048250042010000100007

Merlino LA, Curtis J, Mikuls TR, Cerhan JR, Criswell LA, Saag KG (2004) Vitamin D intake is inversely associated with rheumatoid arthritis: results from the Iowa Women's Health Study. Arthritis Rheum 50: 72-77. https://doi.org/10.1002/art.11434

Myasoedova E, Davis J, Matteson EL, Crowson CS (2020) Is the epidemiology of rheumatoid arthritis changing? Results from a population-based incidence study, 1985-2014. Ann Rheum Dis 79: 440-444. http://dx.doi.org/10.1136/annrheumdis-2019-216694

Polasik K, Piotrowska E, Lipinska B, Witkowski JM, Bryl E, Tukaj S (2017) Vitamin D status in patients with rheumatoid arthritis: a correlation analysis with disease activity and progression, as well as serum IL-6 levels. Acta Biochim Polon 64: 667-670. https://doi. org/10.18388/abp.2017_1636

Rossini M, Maddali Bongi S, La Montagna G, Minisola G, Malavolta N, Bernini L, Cacace E, Sinigaglia L, Di Munno O, Silvano Adami (2010) Vitamin D deficiency in rheumatoid arthritis: prevalence, determinants and associations with disease activity and disability. $A r$ thritis Res Ther 12: R216. https://doi.org/10.1186/ar3195

Sahebari M, Mirfeizi Z, Rezaieyazdi Z, Rafatpanah H, Goshyeshi L (2014) $25(\mathrm{OH})$ vitamin $D$ serum values and rheumatoid arthritis disease activity (DAS28 ESR). Caspian I Int Med 5: 148-155

Șuța C, Şuța M, Craiu E (2014) Prevalence of rheumatoid arthritis in Caucasian population across Europe. Romanian J Rheumatol 4: 169174

Tan LM, Long TT, Guan XL, Wu SF, Zheng W, Fu HY, Wang QH, Meng YM, Wu Y, Zeng TT, Tian YJ, Yu JL, Chen JJ, Li H, CaO LP (2018) Diagnostic value of vitamin D status and bone turnover markers in rheumatoid arthritis complicated by osteoporosis. Ann Clin Lab Sci 48: 197-204

Tetlow LC, Smith SJ, Mawer EB, Woolley DE (1999) Vitamin D receptors in the rheumatoid lesion: expression by chondrocytes, macrophages, and synoviocytes. Ann Rheum Dis 58: 118-121.

Turhanoğlu AD, Güler H, Yönden Z, Aslan F, Mansuroglu A, Ozer C (2010) The relationship between vitamin D and disease activity and functional health status in rheumatoid arthritis. Rheumatol Int 31: 911-914. https://doi.org/10.1007/s00296-010-1393-6

Vojinovic J, Tincani A, Sulli A, Soldano S, Andreoli L, Dall'Ara F, Ionescu R, Simic Pasalic K, Balcune I, Ferraz-Amaro I, Tlustochowicz M, Butrimiene I, Punceviciene E, Toroptsova N, Grazio S, Morovic-Vergles J, Masaryk P, Otsa K, Bernardes M, Boyadzhieva V, Salaffi F, Cutolo M (2017) European multicentre pilot survey to assess vitamin D status in rheumatoid arthritis patients and early development of a new Patient Reported Outcome questionnaire (D-PRO). Autoimmun Rev 16: 548-554. https://doi.org/10.1016/j. autrev.2017.03.002

Watson RR (2013) Handbook of vitamin D in human health: Prevention, treatment and toxicity. In Defining vitamin $D$ deficiency. Wageningen Academic Publishers, pp 551-552. http://dx.doi. org/10.3920/978-90-8686-765-3 